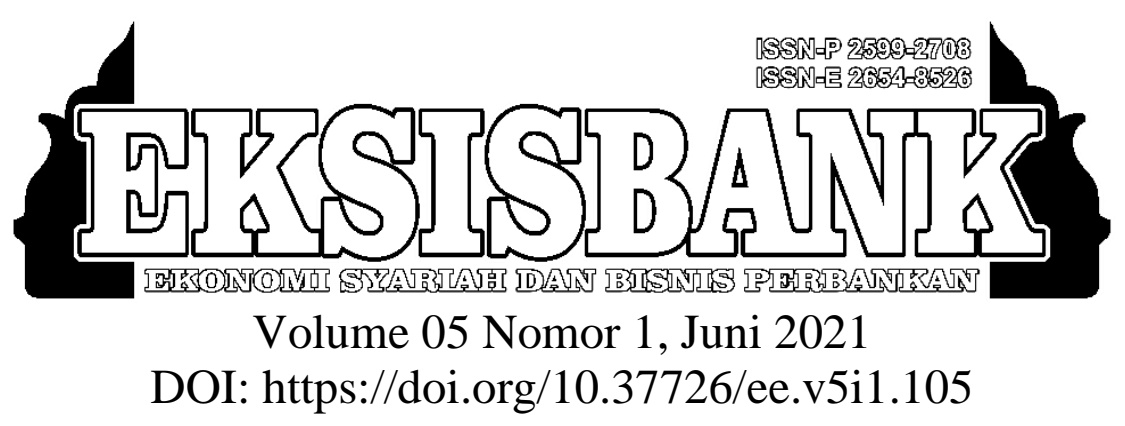

\title{
Tinjauan Ekonomi Syariah Dalam Sewa Menyewa Produk Indihome Di PT. Telkom Kandatel Purwakarta
}

\author{
Luthfi Rahman ${ }^{1}$, Asep Dede Kurnia ${ }^{2}$, Saepul Bahri ${ }^{3}$ Ahmad Ali Sopian ${ }^{4}$ \\ ${ }^{1,2,3}$ Sekolah Tinggi Ilmu Ekonomi Syariah (STIES) Indonesia Purwakarta \\ ${ }^{1}$ rahmanluthfi004@gmail.com \\ 2asepdedekurnia@gmail.com \\ ${ }^{3}$ saefulbahri@gmail.com \\ ${ }^{4}$ Magister Ekonomi Syariah, UIN Sunan Gunung Djati Bandung \\ 4aalsopian24@gmail.com
}

\begin{abstract}
ABSTRAK
Telkom merupakan BUMN yang bergerak di bidang jasa layanan telekomunikasi dan jaringan di wilayah Indonesia. Salah satu produk dari Telkom yaitu IndiHome. Dalam IndiHome sistem perjanjian perusahaan dengan konsumen adalah sewa-menyewa alat atau perangkat untuk dipakai konsumen agar terkoneksi dengan IndiHome kemudian konsumen membayar setiap bulan untuk memperpanjang sewa tersebut. Berdasarkan ketentuan landasan teori dalam islam bahwa sewa menyewa merupakan salah satu bentuk kegiatan muamalah dalam memenuhi kebutuhan hidup manusia, dalam konsep ekonomi syariah sewa-menyewa disebut dengan (alijarah), yang mempunyai rukun dan syarat yang menjadi ketentuan sah nya akad ijarah tersebut. Tujuan dari penelitian ini adalah untuk mengetahui praktik sewa-menyewa IndiHome di PT. Telkom Indonesia Kandatel Purwakarta dan untuk mengetahui tinjauan ekonomi syariah dalam sewa menyewa produk indihome di PT. Telkom Kandatel Purwakarta. Jenis penelitian yang digunakan adalah penelitian lapangan (field research), adapun pendekatan yang digunakan dalam penelitian ini adalah pendekatan deskriptif-kualitatif. Mekanisme yang dilakukan dalam sewa menyewa IndiHome memiliki ketentuan sesuai prosedur perusahaan. Proses transaksi dilakukan dengan pelanggan registrasi melalui offline dilakukan secara langsung dan online melalui aplikasi My IndiHome dan Call Centre ke PT.Telkom dan jika ditinjau dalam ekonomi syariah sewa menyewa IndiHome termasuk kedalam sewa menyewa yang tidak sesuai dengan ketentuan-ketentuan Fatwa Dewan Syariah Nasional Majelis Ulama Indonesia No. 112/DSN-MUI/IX/2017, diantaranya terkait ketentuan mu'jir yang tidak cakap
\end{abstract}


hukum, ketentuan manfaat objek yang tidak bisa disewakan kembali dan waktu sewa yang tidak jelas.

Kata kunci- Telkom, IndiHome, Sewa Menyewa, Ijarah, Mekanisme.

\begin{abstract}
Telkom is a state-owned company engaged in telecommunications and network services in the territory of Indonesia. One of the products from Telkom is IndiHome. In IndiHome, the company's agreement system with consumers is to rent tools or devices for consumers to use to connect with IndiHome, then consumers pay monthly to extend the lease. Based on the basic provisions of the theory in Islam that leasing is a form of muamalah activity in meeting the needs of human life, in the sharia economic concept, leasing is called (al-ijarah), which has the pillars and conditions that become the legal provisions of the ijarah contract. The purpose of this study was to determine the practice of renting IndiHome at PT. Telkom Indonesia Kandatel Purwakarta and to find out an overview of the sharia economy in leasing indihome products at PT. Telkom Kandatel Purwakarta. The type of research used is field research, while the approach used in this research is a descriptive-qualitative approach. The mechanism used in leasing IndiHome has provisions according to company procedures. The transaction process is carried out with customer registration via offline, carried out directly and online through the My IndiHome application and Call Center to PT.Telkom and if viewed in the sharia economy, IndiHome leases are included in leases that are not in accordance with the provisions of the Fatwa of the National Sharia Council of the Ulama Council. Indonesia No. 112/DSNMUI/IX/2017, including those related to mu'jir provisions that are not legally competent, provisions on benefits of objects that cannot be leased back and unclear rental times.
\end{abstract}

Keywords - Telkom, IndiHome, Lease Rentals, Ijarah, Mechanisms.

\section{PENDAHULUAN}

Banyak media komunikasi terkini bermunculan yang biasa disebut dengan media baru (new media). Salah satu media baru yang kini banyak digunakan adalah internet, karena memiliki kemampuan menyebarkan, dan menyampaikan informasi secara cepat tanpa hambatan ruang dan waktu. Hampir semua media dan kebutuhan manusia terhubung dengan internet. Pengguna internet tidak mengenal usia, baik muda, remaja, orang tua, karena sangat mudah untuk diakses dimana saja, dan kapan saja.

Penggunaan media yang berlebihan seringkali dinilai sebagai sesuatu yang berbahaya dan tidak sehat (terutama bagi anak-anak), mendorong kecanduan, keterasingan dan realitas, mengurangi kontak sosial, pengalihan dari pendidikan, dan pergeseran aktivitas yang lebih berguna. Televisi telah menjadi tertuduh utama, tetapi film dan komik dahulu juga dianggap demikian, sementara video game, komputer, dan internet adalah pelaku kriminal terakhir (McQuail 2011).

Melihat banyaknya pengguna internet pada jaman sekarang ini, telah mendorong berbagai perusahaan untuk bergerak di bidang usaha telekomunikasi dan informasi yang menyediakan jasa layanan internet salah satunya adalah PT. Telkom Indonesia. Akses internet dari PT Telkom Indonesia perlu menyebar luas diseluruh Indonesia untuk menunjang kebutuhan masyarakat agar terpenuhi sampai ke daerah-daerah yang jauh dari kota, hal ini dibuktikan dengan adanya

EKSISBANK (Ekonomi Syariah dan Bisnis Perbankan), Volume 5, Nomor 1, Juni 2021 
kantor PT Telkom diberbagai daerah salah satunya PT Telkom Indonesia Kandatel Purwakarata yang menjadi salah satu cabang agar kabupaten Purwakarta dapat merasakan produk produk PT Telkom Indonesia dan salah satu produk PT. Telkom yang paling banyak diminati adalah Indihome (Admin 2019).

Mekanisme IndiHome sistem perjanjian perusahaan dengan konsumen adalah sewamenyewa alat atau perangkat untuk dipakai konsumen agar terkoneksi dengan IndiHome kemudian konsumen membayar setiap bulan untuk memperpanjang sewa tersebut. Dalam sewa menyewa tersebut konsumen harus mendaftar ke Plaza Telkom kemudian mendapatkan verifikasi dari pihak Telkom bahwa persyaratan sudah sesuai dengan kriteria Telkom maka dilakukan akad untuk berlangganan dengan syarat dan ketentuan yang ada.

Berdasarkan ketentuan landasan teori dalam islam bahwa sewa menyewa merupakan salah satu bentuk kegiatan muamalah dalam memenuhi kebutuhan hidup manusia, dalam konsep ekonomi syariah sewa-menyewa disebut dengan (al-ijarah), yang mempunyai rukun dan syarat yang menjadi ketentuan sah nya akad ijarah tersebut. Rukun dan syarat yang harus terpenuhi diantaranya, Shigat, Ujrah (biaya/upah), pelaku sewa menyewa yang meliputi mu'jir dan musta'jir, objek akad meliputi manfaat aset/ma'jur dan pembayaran sewa atau manfaat jasa dan pembayaran upah.

Dilihat dari pemaparan di atas penulis tertarik meneliti dan mengkaji lebih dalam tentang mekanisme sewa menyewa yang diterapkan Indihome PT. Telkom Indonesia. Maka dari itu saya ingin membuat sebuah penelitian dengan judul "Tinjauan Ekonomi Syariah Dalam Sewa-Menyewa Produk Indihome Di PT. Telkom Kandatel
Purwakarta". Tujuan dari penelitian ini adalah untuk mengetahui praktik sewa-menyewa IndiHome di PT. Telkom Indonesia Kandatel Purwakarta dan untuk mengetahui kesesuain praktek sewa-menyewa IndiHome dengan konsep ijarah dalam ekonomi Islam.

\section{A. Pengertian Ijarah}

Ijarah dipahami dalam dua dimensi kehidupan. Ijarah dimaknai sebagai proses perjanjian para pihak, salah satu pihak berkedudukan sebagai penyedia barang/jasa (mu'jir) dan pihak lain berkedudukan sebagai pengguna/penerima manfaat barang/jasa (mustajir). Arti ijarah secara bahasa sebagaimana dijelaskan dalam Qamus alMuhith karya al-Fizuz Abadi, adalah jual-beli manfaat. Ijarah merupakan kata dasar (al-fi;l). Oleh karena itu, arti ijarah secara etimologi adalah imbalan atas perbuatan (Agus Putra et al. 2020).

Amir Syarifuddin mendefinisikan al-ijarah secara sederhana dapat diartikan dengan akad atau transaksi manfaat atau jasa dengan imbalan tertentu. Bila yang menjadi objek transaksi adalah manfaat atau jasa dari suatu benda disebut ijarah al ain, seperti sewa menyewa rumah untuk ditempati. Bila yang menjadi objek transaksi manfaat atau jasa dari tenaga seseorang disebut ijarah ad-Dzimmah atau upah mengupah, seperti upah mengetik skripsi. Sekalipun obyeknya berbeda keduanya dalam konteks fiqh disebut alijarah (Sari et al. 2019).

Pengertian di atas disimpulkan, bahwa yang dimaksud dengan ijarah adalah suatu perjanjian tentang pemakaian dan pengambilan manfaat dari suatu benda, binatang, atau manusia. Dalam hal ini bendanya tidak berkurang sama sekali. Namun, terjadinya akad ijarah tersebut, yang berpindah hanyalah manfaat dari benda yang disewakan baik berupa manfaat barang, seperti kendaraan, rumah, tanah maupun

EKSISBANK (Ekonomi Syariah dan Bisnis Perbankan), Volume 5, Nomor 1, Juni 2021 
manfaat tenaga serta pikiran orang dalam (Suripto and Salam 2018).

\section{B. Rukun dan Syarat}

Menurut Hanafiyah rukun ijarah hanya satu yaitu ijab dan qabul dari dua belah pihak yang bertransaksi. Adapun menurut jumhur ulama ijarah ada empat yaitu:

1. Dua orang yang berakad

2. Sighat (ijab dan qabul)

3. Sewa atau imbalan

4. Manfaat (Syafei 2011)

Adapun syarat-syarat al-ijarah sebagaimana yang ditulis Nasrun Haroen sebagai berikut:

1. Terkait dengan dua orang yang berakad.

2. Kedua belah pihak yang berakad menyatakan kerelaan melakukan akad alijarah.

3. Manfaat yang menjadi objek al-ijarah harus diketahui, sehingga tidak muncul perselisihan dikemudian hari.

4. Objek al-ijarah itu boleh diserahkan secara dan digunakan secara langsung dan tidak ada cacatnya.

5. Objek al-ijarah itu sesuatu yang dihalalkan oleh syara'.

6. Sesuatu yang disewakan itu bukan suatu kewajiban bagi penyewa, misalnya menyewa orang untuk melakukan shalat untuk diri penyewa atau menyewa orang yang belum haji untuk menggantikan haji penyewa.

7. Objek al-ijarah itu merupakan sesuatu yang biasa disewakan seperti, rumah, kendaraan, dan alat-alat perkantoran.

8. Upah atau sewa dalam al-ijarah harus jelas, tertentu, dan sesuatu yang memiliki nilai ekonomi (Ghazaly, Ihsan, and Shidiq 2010).

\section{Jenis-jenis Ijarah}

Dilihat dari Obyeknya ijarah dapat dibagi menjadi dua macam; yaitu ijarah yang bersifat manfaat dan yang bersifat pekerjaan.

1. Ijarah yang bersifat manfaat (Hasan 2003)

Akad sewa manfaat yang bersinggungan langsung dengan bendanya, seperti menyewakan tanah pekarangan, hewan pengangkut yang telah ditentukan, dan mempekerjakan orang tertentu untuk melakukan pekerjaan tertentu (Zuhaili 2010).

2. Ijarah Yang Bersifat Pekerjaan

Ijarah yang bersifat pekerjaan (Al- Ijarah ala al- a'mal); yaitu dengan cara mempekerjakan seseorang untuk melakukan sesuatu. Mu'jir adalah orang yang mempunyai keahlian, tenaga, jasa dan lain-lain. Musta'jir adalah pihak yang membutuhkan keahlian, tenaga atau jasa tersebut dihargai dengan imbalan tertentu. Mu'jir mendapatkan upah (ujrah) atas tenaga yang ia keluarkan untuk musta'jir dan Musta'jir mendapatkan tenaga atau jasa dari mu'jir (Afandi 2010).

\section{Berakhirnya Akad Ijarah}

Menurut Sayyid Sabiq, akad al-ijarah dapat menjadi batal dan berakhir apabila ada hal-hal sebagai berikut:

1. Terjadinya cacat pada barang sewaan ketika ditangan penyewa.

2. Rusaknya barang yang disewakan, seperti ambruknya rumah runtuhnya bangunan gedung. Rusaknya barang yang diupahkan, seperti bahan baju yang diupahkan untuk dijahit.

3. Telah terpenuhinya manfaat yang diakadkan sesuai dengan masa yang telah ditentukan dan selesainya pekerjaan.

Menurut Hanafiyah salah satu pihak dari yang berakad boleh membatalkan akad alijarah jika ada kejadian-kejadian yang luar biasa, seperti terbakarnya gedung, tercurinya 
barang-barang dagangan, dan kehabisan modal (Ghazaly, Ihsan, and Shidiq 2010).

\section{TINJAUAN PUSTAKA}

Penelitian tentang Tinjauan Ekonomi Syariah dalam Sewa Menyewa Produk IndiHome sudah banyak dilakukan penelitianpenelitian oleh peneliti sebelumnya, seperti penelitian sebagai berikut:

A. Perlindunganhukum Konsumen Indihome

Terhadap Kebijakan Sepihak Oleh Pt.

Telekomunikasi Indonesia. (Setiaji 2017)

Adanya penelitian ini dilatarbelakangi dengan adanya kerugian terhadap konsumen dikarenakan kurang adanya informasi yang diberikan dari pihak indihome terhadap konsumennya sehingga praktek yang di berikan indihome terhadap konsumen terkadang tidak sesuai dengan apa yang di berikan terhadap konsumen seperti contohnya berlangganan dengan harga yang sama mendapatkan tiga fasilitas yaitu: tv kabel, internet, dan telfon intrlokal gratis, akan tetapi praktek yang di berikan pada bulan februari 2016 salah satu chanel tv kabel ada yang hilang dengan alasan pihak Telkom dan chanel tv tersebut sudah tidak bekerja sama, akan tetapi pada bulan maret chanel tersebut sudah kembali ada dalam paketan indihome tetapi apabila konsumen ingin menikmati program chanel tersebut harus menambah biaya untuk mendapatkan chanel tersebut.

Peneliti terdahulu meneliti Perlindungan hukum Konsumen Indihome Terhadap Kebijakan Sepihak Oleh PT. Telekomunikasi Indonesia, dimana peneliti terdahulu peneliti terkait paketan indihome yang pada saat penawaran dan setelah di pasang/ digunakan oleh konsumen terjadi ketidak sesuaian apa yang di sampaikan pada saat sebelum pemasangan dan sesudah pemasangan indihome. Sedangkan pada penelitin saat ini peneliti hanya mengkaji tinjauan Ekonomi Syariah dalam Sewa Menyewa Produk
IndiHome di PT. Kandatel Purwakarta, penelitian ini hanya terfokus pada produk Rooter yang sering di sewakan oleh pihak perusahaan kepada pihak konsumen.

B. Tinjauan Hukum Islam Terhadap Pembayaran Upah Tambahan Pemasangan Wifi Indihome (Studi Di Kelurahan Susunan Baru, Kecamatan Tanjung Karang Barat, Bandar Lampung) (MUHAMMAD 2021)

Upah-mengupah adalah bentuk tolongmenolong antara sesama umat manusia untuk memenuhi kebutuhan hidupnya yakni dengan cara memanfaatkan tenaga orang lain dengan jalan memberikan imbalan menurut syarat tertentu. Pihak indihome mempunyai kebijakan dan aturan yang telah dibuat atau disebut juga Syarat dan Ketentuan indihome. Dalam pemasangan wifi indihome bentuk pembayaran upah telah ditentukan oleh pihak indihome dan merupakan kebijakan dari pihak indihome, costumer wifi indihome membayar biaya administrasi dan costumer dikenakan biaya pasang baru diawal pembayaran setelah registrasi, kemudian bagi costumer yang sudah melakukan registrasi dan sudah membayar biaya administrasi, petugas teknisi indihome akan menginstalasinya. Setelah menginstalasi wifi indihome, petugas teknisi meminta biaya tambahan costumer, yang biaya tersebut sudah dibayarkan diawal dan ini tidak sesuai dengan kesepakatan, sehingga costumer indihome melakukan pembayaran upah tambahan yang diminta petugas teknisi indihome.

Peneliti terdahulu meneliti tinjauan Hukum Islam Terhadap Pembayaran Upah Tambahan Pemasangan Wifi Indihome (Studi Di Kelurahan Susunan Baru, Kecamatan Tanjung Karang Barat, Bandar Lampung), dimana peneliti terdahulu mengkaji terkait upah tambahan pemasangan Wifi Indihome yang kadang ditemukan ketidak sesuain apa 
yang disampaikan sebelum pemasangan dan setelah atau saat pemasangan sedang berlangsung muncul biaya administrasi A, Adminisrasi B dan lain sebagainya yang diluar dari kesepakatan custome. Sedangkan pada penelitin saat ini peneliti fokus mengkaji tinjauan Ekonomi Syariah dalam Sewa Menyewa Produk IndiHome di PT. Kandatel Purwakarta, penelitian ini hanya terfokus pada produk Rooter yang sering di sewakan oleh pihak perusahaan kepada pihak konsumen.

C. Klausula Eksemsi dalam Kontrak Berlangganan Internet PT.Telekomunikasi Indonesia Wilayah Aceh Ditinjau menurut Konsep Perlindungan Konsumen dalam Hukum Islam (Suatu Penelitian di Kota Banda Aceh) (Fina Anisa 2018)

Penelitian ini bertujuan untuk mencari jawaban terhadap persoalan pokok bagaimana bentuk pertanggungjawaban PT.Telkom atas tidak terpenuhinya perjanjian dalam kontrak berlangganan internet pada PT.Telkom dan bagaimana tinjauan perlindungan konsumen dalam hukum Islam terhadap klausula eksemsi yang terdapat dalam kontrak berlangganan internet pada PT.Telkom. Perolehan data dalam skripsi ini menggunakan metode kualitatif dengan jenis penelitian deskriptif analisis melalui data dari penelitian lapangan (field research) dan penelitian kepustakaan (library research) dan data tersebut diperoleh melalui wawancara, dokumentasi dan literatur-literatur lainnya yang berhubungan dengan objek penelitian. Hasil penelitian menunjukkan bahwa, perjanjian baku tersebut memuat beberapa klausula eksemsi yang membatasi tanggung jawab, di mana PT.Telkom bertanggungjawab apabila kesalahannya di akibatkan oleh PT.Telkom. Namun, kontrak baku tersebut bersifat final dan tidak dapat direvisi oleh pelanggan. Pencantuman klausula eksemsi dalam kontrak tersebut belum di sesuaikan dengan asas-asas perikatan agar terciptanya nilai-nilai keagamaan, keadilan (al-'Adalah), kemaslahatan, persamaan dan kesetaraan (alMusawah), dengan tidak mengesampingkan nilai-nilai sosial dan kemanusiaan (hablum minallah wa hablum minannas). Oleh karena itu, diharapkan bagi pelaku usaha untuk tidak menambahkan klausula yang membatasi tanggung jawab/klausula yang memberatkan bagi konsumen, agar terciptanya kontrak yang seimbang/adil dan saling ridha di antara kedua belah pihak.

Peneliti terdahulu meneliti Klausula Eksemsi dalam Kontrak Berlangganan Internet PT. Telekomunikasi Indonesia Wilayah Aceh Ditinjau menurut Konsep Perlindungan Konsumen dalam Hukum Islam, penelitian tersebut focus mengkaji isi kontrak atau klausula yang dianggap memberatkan satu pihak saja yakni pihak konsumen. Konsumen tidak bisa merubah isi kontrak tersebut, padahal dalam islam kontrak harus berdasarkan kesepakatan kedua belah pihak termasuk sisi kemashlahatannya harus bisa dirasakanoleh semua pihak. Sedangkan pada penelitin saat ini peneliti fokus mengkaji tinjauan Ekonomi Syariah dalam Sewa Menyewa Produk IndiHome di PT. Kandatel Purwakarta, penelitian ini hanya terfokus pada produk Rooter yang sering di sewakan oleh pihak perusahaan kepada pihak konsumen tidak mengkaji isi kontrak atau klausula yang dianggap memberatkan pihak konsumen.

D. Wanprestasi Dalam Kontrak Berlangganan Layanan Indihome (Suatu Penelitian Pada Pt. Telkom Indonesia Banda Aceh) (ULUL AZMI 2021)

Hasil penelitian menunjukkan bahwa terjadinya wanprestasi adalah karena ada kelalaian dari pelanggan yang tidak membaca isi kontrak dengan baik, Bentuk-bentuk wanprestasi yaitu tidak memenuhi kewajiban dalam membayar uang kepada pihak 
Indhohome, isi kontrak tidak jelas. Upayaupaya penyelesaian yang dilakukan pihak Indohome Kota Banda Aceh dalam menyelesaikan perkara dengan pelanggan, dapat diselesaikan dengan sebaik-baiknya, Penyelesaian wanprestasi yang ditempuh oleh pihak PT. Tekom maupun pelanggan dengan cara bermusyawarah antara PT. Telkom maupun pelanggan untuk mencari solusi, agar permasalahan tersebut dapat terselesaikan dengan baik, upaya yang kedua dengan jalur hukum, ketika tidak dapat diselesaikan dengan musyawarah maka jalan terakhir yang ditempuh dengan jalur hukum. Diharapkan kepada pelanggan agar membaca lebih teliti isi kontrak sebelum pemasangan wifi. Diharapkan kepada pelanggan jika melakukan pemasangan wifi kepada PT. Telkom, agar memperhatikan dengan teliti cicilannya perbulan sehingga tidak keberatan ketika membayar cicilannya perbulan.

Peneliti terdahulu meneliti Wanprestasi Dalam Kontrak Berlangganan Layanan Indihome di PT. Telkom Indonesia Banda Aceh, penelitian tersebut mengkaji bentukbentuk wanprestasi seperti tidak memenuhi kewajiban dalam membayar uang kepada pihak Indhohome, isi kontrak tidak jelas. Sedangkan pada penelitin saat ini peneliti fokus mengkaji tinjauan Ekonomi Syariah dalam Sewa Menyewa Produk IndiHome di PT. Kandatel Purwakarta, penelitian ini hanya terfokus pada produk Rooter yang sering di sewakan oleh pihak perusahaan kepada pihak konsumen tidak mengkaji wanprestasi pihak konsumen terhadap pihak PT. Telkom Indonesia.

\section{METODOLOGI PENELITIAN}

Jenis penelitian ini adalah penelitian lapangan (field research) yaitu penelitian yang objeknya mengenai gejala-gejala atau peristiwa-peristiwa yang terjadi pada kelompok masyarakat. Sehingga penelitian ini juga bisa disebut penelitian kasus atau study kasus (case study) dengan pendekatan deskriptif kualitatif (Arikunto 2016).

Penelitian kualitatif yaitu penelitian yang menghasilkan prosedur analisis yang tidak menggunakan prosedur analisis statistik atau cara kuantifikasi lainnya (Jalaludin and Komarujaman 2018). Jelas bahwa pengertian ini mempertentangkan penelitian kualitatif dengan penelitian yang bernuansa kuantitatif yaitu dengan menonjolkan bahwa usaha kuantifikasi apapun tidak perlu digunakan pada penelitian kualitatif.

Penelitian ini difokuskan di PT. Telkom Kandatel Purwakarta. Alamat: JL. K.K Singawinata No.106, Nagri Kidul, Kecamatan Purwakarta, Kabupaten Purwakarta, Jawa Barat, 41111, Indonesia. Waktu penelitian dimulai dari bulan agustus dilakukan sesuai jadwal yang ditentukan pihak PT. Telkom yang biasanya memberikan satu hari dalam seminggu untuk bisa melakukan penelitian dengan membuat janji kepada pihak yang bersangkutan.

Teknik pengumpulan data merupakan cara yang dilakukan peneliti untuk mengungkap atau menjaring informasi dari responden sesuai lingkup penelitian. Berikut ini ada beberapa teknik pengumpulan data:

\section{A. Wawancara}

Penelitian ini menggunakan jenis wawancara terbuka dan terstruktur, arti dari wawancara terbuka itu sendiri adalah wawancara yang para subjeknya tahu bahwa mereka sedang diwawancarai dan mengetahui pula apa maksud dan tujuan wawancara itu (Moleong 2017). Wawancara terstruktur adalah wawancara yang pewawancaranya menetapkan sendiri masalah da pertanyaan-pertanyaan yang akan diajukan (Moleong 2017). Penelitian ini dilakukan secara terstruktur dan terbuka, dimana yang diwawancarai baik pihak karyawan dan konsumen

EKSISBANK (Ekonomi Syariah dan Bisnis Perbankan), Volume 5, Nomor 1, Juni 2021 
IndiHome telah mengetahui apa maksud dan tujuan pewawancara dan susunan pertanyaan telah disiapkan sesuai apa yang akan ditanyakan dana pa yang ingin didapatkan untuk dijadikan sumber data. Wawancara dilakukan kepada pihak yang terlibat, yaitu staff dan pengguna IndiHome. Waktu dan tempat dilakukan dengan wawancara ini adalah secara langsung.

Wawancara dalam penelitian ini dilakukan sebanyak 2 kali dengan staff dan karyawan PT. Telkom Kandatel Purwakarta dan 4 kali dengan pelanggan IndiHome, wawancara awal dimulai pada bulan agustus untuk wawancara dengan karyawan yaitu dengan Bapak Ridwan dan Bapak Deni, dan untuk pengguna IndiHome dengan Ibu Siti Aminah, Bapak Darsuki dan Bapak Royyan.

B. Observasi

Observasi penelitian ini dilakukam dengan cara pengamatan secara intensif terhadap objek yang diteliti yaitu mekanisme sewa menyewa IndiHome di PT. Telkom Kandatel Purwakarta. Melakukan pencatatan secara sistemik terhadap halhal yang berkaitan dengan penelitian tersebut

Observasi yang dilakukan dalam penelitian ini adalah jenis observasi pasif (passive participation) adalah jenis obervasi yang dalam hal ini peneliti datang di tempat kegiatan orang yang diamati, tetapi tidak ikut terlibat dalam kegiatan tersebut. Maka, dalam penelitian ini peneliti hanya mengamati dan observasi secara langsung dengan cara datang dan mengamati mekanisme sewa menyewa IndiHome.

C. Dokumentasi
Dokumentasi merupakan salah satu bukti bahwa penulis bernar melakukan penelitian (Jaelani, Sucipto, and Jalaludin 2020). Dokumentasi penulis berupa foto, dan hasil dari wawancara. Dokumen yang didapat dari sini adalah dokumen data laporan dokumen berita acara layanan pelanggan, dokumentasi wawancara, dokumentasi SOP mekanisme sewa menyewa.

Sumber data adalah subjek dari mana asal data penelitian itu diperoleh. Dalam melakukan penelitian ini data-data yang diperlukan diperoleh dari dua sumber yaitu:

1. Data Primer

Data primer adalah data yang dikumpulkan dan diolah sendiri oleh suatu organisasi atau perorangan langsung dari objeknya. Pengumpulan data tersebut dilakukan secara khusus untuk mengatasi masalah riset yang sedang diteliti. Sumber primer dalam penelitian ini didapat dari hasil wawancara yang dilakukan terhadap pihak PT. Telkom Kandatel Purwakarta dan pelanggan IndiHome

2. Data Sekunder

Data sekunder adalah data yang diperoleh dalam bentuk yang sudah jadi, sudah dikumpulkan dan diolah oleh pihak lain, biasanya sudah dalam bentuk publikasi. Data semacam ini sudah dikumpulkan pihak lain untuk tujuan tertentu yang bukan untuk keperluan riset yang sedang dilakukan peneliti saat ini secara spesifik (Suryani and Hendryadi 2015). Sumber sekunder penelitian ini diperoleh dari data atau arsip buku-buku referensi, dan situs website.

Analisis data adalah proses mencari dan menyusun secara sistematis data yang diperoleh dari hasil wawancara, catatan lapangan, dan bahan-bahan lain, sehingga

EKSISBANK (Ekonomi Syariah dan Bisnis Perbankan), Volume 5, Nomor 1, Juni 2021 http://journal.sties-purwakarta.ac.id/index.php/EKSISBANK/ 
dapat mudah dipahami, dan temuannya dapat diinformasikan kepada orang lain (Sugiyono 2017). Analisis data dalam penelitian kualitatif dilakukan sejak sebelum memasuki lapangan, selama di lapangan dan setelah selesai di lapangan. Aktivitas dalam analisis data, yaitu: data reduction, data display, dan conclusion drawing/verification (Sugiyono 2016).

\section{A. Data Reduksi (Data Reduction)}

Menurut Milles dan Huberman, mereduksi data adalah merangkum, memilih hal-hal yang pokok, memfokuskan pada hal-hal yang penting, dicari tema dan polanya. Dengan demikian data yang telah direduksi akan memberikan gambaran yang lebih jelas, dan mempermudah peneliti untuk melakukan pengumpulan data selanjutnya dan mencarinya bila diperlukan sehingga disusun secara sistematis dan mudah dikendalikan.

B. Penyajian data (data display)

Setelah data direduksi maka langkah selanjutnya adalah mendisplaykan data yang dapat dilakukan dalam bentuk tabel, grafik, pictogram dan sejenisnya. Melalui penyajian data tersebut maka data terorganisasikan, tersusun dalam pola hubungan, sehingga akan semakin mudah dipahami dalam rangka memperoleh kesimpulan sebagai temuan penelitian.

C. Penarikan kesimpulan atau verifikasi (conclusion drawing/verification)

Langkah ketiga dalam analisis data kualitatif menurut Miles dan Huberman adalah penarikan kesimpulan dan verifikasi. Kesimpulan awal yang dikemukakan masih bersifat sementara, dan akan berubah bila tidak ditemukan bukti-bukti yang kuat yang mendukung pada tahap pengumpulan data berikutnya. Tetapi apabila kesimpulan yang dikemukakakn pada tahap awal, didukung oleh bukti-bukti yang valid dan saat peneliti kembali ke lapangan mengumpulkan data, maka kesimpulan yang dikemukakan merupakan kesimpulan yang kredibel.

Keabsahan data dalam penelitian ini ditentukan dengan menggunakan kriteria kredibilitas. Untuk mendapatkan data yang relevan, maka peneliti melakukan pengecekan keabsahan data hasil penelitian dengan cara:

a) Perpanjangan Pengamatan

Dalam penelitian ini peneliti melakukan perpanjangan pengamatan, dengan kembali lagi ke lapangan untuk memastikan apakah data yang telah penulis peroleh sudah benar atau masih ada yang salah.

b) Ketekunan Pengamatan

Meningkatkan ketekunan berarti melakukan pengamatan secara lebih cermat dan berkesinambungan (Meirani, Damiri, and Jalaludin 2020). Dengan cara tersebut maka kepastian data dan urutan peristiwa akan dapat direkam secara pasti dan sistematis (Sugiyono 2017). Meningkatkan ketekunan itu ibarat kita mengecek soal- soal, atau makalah yang telah dikerjakan, apakah ada yang salah atau tidak. Dengan meningkatkan ketekunan itu, maka peneliti dapat melakukan pengecekan kembali apakah data yang telah ditemukan itu salah atau tidak. Demikian juga dengan meningkatkan ketekunan maka, peneliti dapat memberikan deskripsi data yang akurat dan sistematis tentang apa yang diamati (Sugiyono 2013).

c) Triangulasi

Dalam penelitian ini menggunakan triangulasi sumber. Triangulasi sumber digunakan untuk pengecekan data tentang keabsahannya, membandingkan hasil

EKSISBANK (Ekonomi Syariah dan Bisnis Perbankan), Volume 5, Nomor 1, Juni 2021 
wawancara dengan isi suatu dokumen dengan memanfaatkan berbagai sumber data informasi sebagai bahan pertimbangan. Dalam hal ini penulis membandingkan data hasil observasi dengan data hasil wawancara, dan juga membandingkan hasil wawancara dengan wawancara lainnya.

\section{HASIL DAN PEMBAHASAN}

\section{A. Praktik sewa-menyewa IndiHome di PT. Telkom Indonesia Kandatel Purwakarta}

Mekanisme sewa menyewa IndiHome sesuai dari data yang didapat bisa menggunakan dua cara yaitu dengan metode offline dan online, untuk offline pelanggan bisa langsung datang ke Plaza Telkom dan sales marketing untuk metode online menggunakan aplikasi My IndiHome dan call centre.

Untuk sistem registrasi secara online pelanggan diminta untuk melengkapi kelengkapan data pelanggan berbentuk softfile yang diunggah di aplikasi my IndiHome yaitu identitas pelanggan kartu tanda penduduk (KTP), alamat pemasangan alamat tujuan yang di pasang, nomer hp, email, foto pelanggan, foto $\mathrm{ktp}$, foto rumah pelanggan, dan tagging pelanggan (koordinat lokasi pemasangan).

Sistem registasi secara offline tidak jauh beda dengan online kelengkapan data juga harus dilengkapi berupa data pelanggan sama dengan registrasi online hanya saja bedanya jika ofline pelanggan harus bertatap langsung mendatangi plaza Telkom dan mendapatkan informasi secara jelas.

Setelah melakukan registrasi dan verifikasi data, ada tindak lanjut dari pihak IndiHome yang akan mengirim teknisi untuk melakukan pengecekan jaringan ke titik tujuan pemasangan, untuk melakukan verifikasi jika verifikasi sudah oke, Setelah semua persyaratan terpenuhi tahap selanjutnya pelanggan dan pihak Telkom melakukan akad dengan menyetujui syarat dan ketentuan yang diberikan oleh Telkom, selanjutnya ke tahap pemasangan IndiHome. Adapun biaya yang dikenakan dalam sewa menyewa IndiHome biaya bervariasi sesuai pilihan paket yang diinginkan.

Syarat dan ketentuan dalam sewa menyewa IndiHome, Sudah memiliki KTP, Lokasi pemasangan, Tidak memiliki tunggakan administrasi ke PT Telkom, Nomor telepon dan email aktif, Foto pelanggan dan rumah asli. Sistem pembayaran sewa menyewa di IndiHome dilakukan setelah penggunaan satu bulan berlangsung.

Pemutusan dapat dilakukan dengan dua pihak atau sebelah pihak. Dua pihak dilakukan jika pelanggan melakukan pemutusan kontrak sesuai dengan prosedur, prosedur dilakukan dengan cara pelanggan datang ke kantor Telkom untuk melakukan konfirmasi bahwa pelanggan sudah tidak melanjutkan untuk berlangganan IndiHome lagi.

Membawa perangkat yang disewa oleh konsumen dari Telkom untuk dikembalikan ke Telkom melalui plaza telkom, pelanggan harus mengisi data diri sesusuai nama yg didaftarkan pertama bila di kuasakan harus menggunaakan surat kuasa, terus membayar sisa tagihan. Kemudian pemutusan secara sepihak hanya dilakukan oleh pelanggan tanpa persetujuan pihak Telkom. Dalam hal ini pelanggan akan mengalami kerugian dikarenakan biaya per bulan akan terus berjalan dan menjadi hutang dari pelanggan itu sendiri jika hutang ini tidak dibereskan, 
maka nama pelanggan tersebut sudah tidak bisa dipakai untuk melakukan transakssi dengan PT. Telkom.

\section{B. Tinjauan Ekonomi Syariah dalam Sewa Menyewa Produk IndiHome di PT. Kandatel Purwakarta}

Hasil observasi serta wawancara yang telah dilakukan di PT. Telkom Kandatel Purwakarta mengenai mekanisme sewa menyewa IndiHome ditinjau dari sudut pandang ekonomi Islam disesuaikan dengan Fatwa Dewan Syariah Nasional Majelis Ulama Indonesia No. 112/DSN-MUI/IX/2017 dibuat dengan tabel kesesuaian sebagai berikut:

Tabel 4.1

Ketentuan terkait shigat

\begin{tabular}{|l|l|c|c|}
\hline No & \multicolumn{1}{|c|}{$\begin{array}{l}\text { Ketentuan } \\
\text { Terkait Shigat }\end{array}$} & Sesuai & $\begin{array}{c}\text { Tidak } \\
\text { Sesuai }\end{array}$ \\
\hline 1. & $\begin{array}{l}\text { Akad ijarah } \\
\text { harus dinyatakan } \\
\text { secara tegas dan } \\
\text { jelas serta } \\
\text { dimengerti oleh } \\
\text { mujir/ajir dan } \\
\text { mustajir }\end{array}$ & $\sqrt{ }$ & \\
\hline 2. & $\begin{array}{l}\text { Akad ijarah } \\
\text { boleh dilakukan } \\
\text { secara lisan, } \\
\text { tertulis, isyarat, } \\
\text { dan } \\
\text { perbuatan/tindak } \\
\text { an, serta dapat } \\
\text { dilakukan secara } \\
\text { elektronik sesuai } \\
\text { syariah dan } \\
\text { peraturan } \\
\text { perundang- } \\
\text { undangan yang } \\
\text { berlaku. }\end{array}$ & $\sqrt{ }$ & \\
\hline
\end{tabular}

Tabel 4.1 di atas menunjukan adanya kesesuaian syariah mengenai shigat dalam mekanisme sewa menyewa IndiHome hal ini berdasarkan wawancara dan observasi. Pada ketentuan shigat poin pertama bahwa dalam akad sewa menyewa IndiHome dilakukan secara jelas oleh pihak IndiHome yang menjelaskan bagaimana tata cara mendaftar menjadi pelanggan. Poin kedua akad sewa menyewa IndiHome dilakukan dengan lisan antara kedua pihak terkait, secara tulisan berbentuk berita acara yang ditandatangani kedua belah pihak dan melalui media elektronik dengan menggunakan aplikasi My IndiHome.

\section{Tabel 4.2}

Ketentuan terkait mu'jir, mustajir dan ajir

\begin{tabular}{|l|l|l|l|}
\hline No & $\begin{array}{l}\text { Ketentuan Terkait } \\
\text { Mu'jir, Mustajir } \\
\text { Dan } \text { Ajir }\end{array}$ & Sesuai & $\begin{array}{c}\text { Tidak } \\
\text { Sesuai }\end{array}$ \\
\hline 1. & $\begin{array}{l}\text { Akad ijarah boleh } \\
\text { dilakukan oleh orang } \\
\text { (syakhshiyah } \\
\text { thabi'iyah/natuurlijke } \\
\text { persoon) maupun } \\
\text { yang dipersamakan } \\
\text { dengan orang baik } \\
\text { berbadan hukum } \\
\text { maupun tidak } \\
\text { berbadan hukum } \\
\text { (syakhshiyah } \\
\text { I'tibariah/s } \\
\text { yakhshiyah hukmiyah } \\
\text { /rechtsperson) } \\
\text { berdasarkan } \\
\text { peraturan perundang- } \\
\text { undangan yang } \\
\text { berlaku. }\end{array}$ & $\checkmark$ & \\
\hline 2. & $\begin{array}{l}\text { Mu'jir, musta'jir dan } \\
\text { ajir wajib cakap } \\
\text { hukum sesuai dengan } \\
\text { syariah dan peraturan } \\
\text { perundang-undangan. }\end{array}$ & & \\
\end{tabular}

EKSISBANK (Ekonomi Syariah dan Bisnis Perbankan), Volume 5, Nomor 1, Juni 2021 http://journal.sties-purwakarta.ac.id/index.php/EKSISBANK/ 


\begin{tabular}{|l|l|c|c|}
\hline No & $\begin{array}{l}\text { Ketentuan Terkait } \\
\text { Mu'jir, Mustajir } \\
\text { Dan Ajir }\end{array}$ & Sesuai & $\begin{array}{c}\text { Tidak } \\
\text { Sesuai }\end{array}$ \\
\hline 3. & $\begin{array}{l}\text { Mu'jir wajib } \\
\text { memiliki } \\
\text { kewenangan } \\
\text { (wilayah) untuk } \\
\text { melakukan akad } \\
\text { ijarah baik } \\
\text { kewenangan yang } \\
\text { bersifat ashliyah } \\
\text { maupun niyabiyyah. }\end{array}$ & $\sqrt{ }$ & \\
\hline 4. & $\begin{array}{l}\text { Mu'jir wajib } \\
\text { memiliki kemampuan } \\
\text { untuk menyerahkan } \\
\text { manfaat. }\end{array}$ & $\sqrt{ }$ & \\
\hline 5. & $\begin{array}{l}\text { Musta'jir wajib } \\
\text { memiliki kemampuan } \\
\text { untuk membayar } \\
\text { ujrah. }\end{array}$ & $\sqrt{ }$ & \\
\hline
\end{tabular}

Tabel 4.2 di atas menjelaskan tentang ketentuan terkait mu'jir, mustajir dan ajr. Pada poin 1 adanya kesesuaian syariah yaitu bahwa pada sewa menyewa IndiHome dapat dilakukan oleh perorangan maupun pihak berbadan hukum ataupun lembaga. Pada poin kedua adanya ketidaksesuaian syariah yaitu terkait kecakapan hukum syariah dan peraturan perundang-undangan bahwasanya pelanggan maupun pihak IndiHome tidak mempunyai kecakapan hukum terhadap hukum syariah. Poin ketiga adanya kesesuaian terkait dengan kewenangan (wilayah) baik ashliyah maupun niyyabiyah bahwasanya dalam sewa menyewa IndiHome kewenangan atas kepemilikan objek sewa yaitu dengan kewenangan sebagai pemilik IndiHome tersebut dan wakil atas kewenangan kepemilikan objek sewa atau IndiHome yang dilakukan oleh mitra PT. Telkom. Poin keempat adanya kesesuaian terkait mu'jir yang memberikan manfaat yaitu pihak Telkom yang memberikan pelayanan jasa IndiHome. Dan poin kelima adanya kesesuaian syariah yaitu terkait musta'jir wajib membayar ujrah yaitu pelanggan yang membayar biaya perbulan.

Tabel 4.3

Ketentuan terkait mahall al-manfaah dalam ijarah 'ala al-a'yan

\begin{tabular}{|c|c|c|c|}
\hline $\begin{array}{l}\mathbf{N} \\
\mathbf{0}\end{array}$ & $\begin{array}{c}\text { Ketentuan } \\
\text { Terkait Mahall } \\
\text { Al-Manfaah } \\
\text { Dalam Ijarah } \\
\text { 'Ala Al-A'yan }\end{array}$ & Sesuai & $\begin{array}{l}\text { Tidak } \\
\text { Sesuai }\end{array}$ \\
\hline 1. & $\begin{array}{l}\text { Mahall al-manfa'ah } \\
\text { dibenarkan (tidak } \\
\text { dilarang) secara } \\
\text { syariah } \\
\text { (mutaqawwam). }\end{array}$ & $\sqrt{ }$ & \\
\hline 2. & $\begin{array}{l}\text { Mahall al-manfa'ah } \\
\text { sebagaimana dalam } \\
\text { huruf a), harus dapa } \\
\text { di serahterimakan } \\
\text { (maqdur al-taslim) } \\
\text { pada saat akad atau } \\
\text { pada waktu yang } \\
\text { disepakati dalam } \\
\text { akad ijarah } \\
\text { maushufah fi al- } \\
\text { dzimmah. }\end{array}$ & $\sqrt{ }$ & \\
\hline
\end{tabular}

Tabel 4.3 di atas menjelaskan ketentuan terkait mahall al-manfa'ah menunjukan adanya kesesuaian syariah pada kedua poin tersebut yaitu bahwa dalam sewa menyewa IndiHome bahwa modem tidak dilarang atau dibenarkan secara syariah. Dan dapat diserahterimakan pada saat akad atau pada waktu yang ditentukan.

Tabel 4.4

\section{Ketentuan terkait manfaat dan waktu} sewa

EKSISBANK (Ekonomi Syariah dan Bisnis Perbankan), Volume 5, Nomor 1, Juni 2021 


\begin{tabular}{|c|c|c|c|}
\hline $\begin{array}{l}\mathbf{N} \\
\mathbf{0}\end{array}$ & $\begin{array}{c}\text { Ketentuan } \\
\text { Terkait Manfaat } \\
\text { Dan Waktu Sewa }\end{array}$ & Sesuai & $\begin{array}{l}\text { Tidak } \\
\text { Sesuai }\end{array}$ \\
\hline 1. & $\begin{array}{lr}\text { Manfaat } & \text { harus } \\
\text { berupa } & \text { manfaat } \\
\text { yang dibenarkan } \\
\text { (tidak dilarang) } \\
\text { secara } & \text { syariah } \\
\text { (mutaqawwam). }\end{array}$ & $\sqrt{ }$ & \\
\hline 2. & $\begin{array}{lr}\text { Manfaat } & \text { harus } \\
\text { jelas } & \text { sehingga } \\
\text { diketahui } & \text { oleh } \\
\text { mu'jir } & \text { dan } \\
\text { musta'jir/Ajir. } & \end{array}$ & $\sqrt{ }$ & \\
\hline 3. & $\begin{array}{l}\text { Tata cara } \\
\text { penggunaan } \\
\text { barang sewa serta } \\
\text { jangka waktu } \\
\text { sewa harus } \\
\text { disepakati oleh } \\
\text { mu'jir dan } \\
\text { musta'jir. }\end{array}$ & & $\sqrt{ }$ \\
\hline 4. & $\begin{array}{l}\text { Musta'jir dalam } \\
\text { akad ijarah 'ala } \\
\text { a;-a'yan, boleh } \\
\text { menyewakan } \\
\text { kembali (al-ijarah } \\
\text { min al-bathin) } \\
\text { kepada pihak lain, } \\
\text { kecuali tidak } \\
\text { diijinkan } \\
\text { (dilarang) oleh } \\
\text { mu'jir. }\end{array}$ & & $\sqrt{ }$ \\
\hline 5. & $\begin{array}{l}\text { Musta'jir dalam } \\
\text { akad ijarah 'ala } \\
\text { al-a'yan, tidak } \\
\text { wajib } \\
\text { menanggung } \\
\text { resiko terhadap } \\
\text { kerugian yang } \\
\text { timbul karena } \\
\text { pemanfaatan, } \\
\text { kecuali karena al- } \\
\text { ta'addi, al- }\end{array}$ & $\sqrt{ }$ & \\
\hline
\end{tabular}

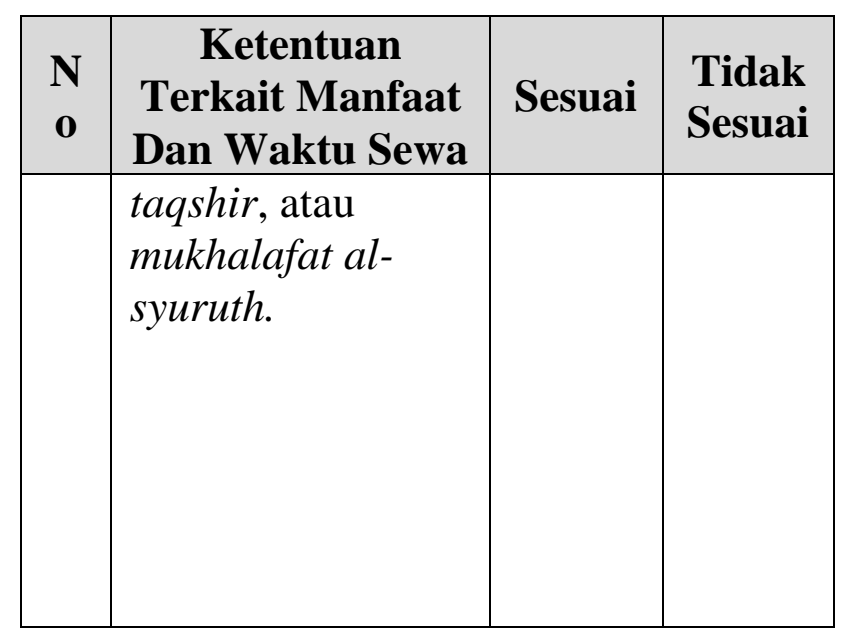

Tabel $4.4 \mathrm{di}$ atas menjelaskan terkait manfaat dan waktu sewa hal ini berdasarkan hasil wawancara bahwa manfaat IndiHome pada poin pertama adanya kesesuaian syariah terkait manfaat harus sesuai syariah bahwa modem bermanfaat sesuai dengan syariah diantaranya ada layanan televisi, layanan internet dan telepon, pada poin kedua adanya kesesuaian terkait manfaat harus diketahui oleh mujir maupun musta'jir dalam sewa menyewa IndiHome sudah jelas, dijelaskan apa saja manfaat dari sewa menyewa IndiHome yang dijelaskan oleh pihak IndiHome sehingga diketahui oleh pelanggan. Poin ketiga, adanya ketidak kesesuaian syariah terkait jangka waktu sewa dalam sewa menyewa IndiHome tidak jelas jangka waktu yang ditetapkan dalam sewa menyewa IndiHome karena waktu sewa terus berjalan selama pelanggan berlangganan IndiHome tersebut. Poin keempat adanya ketidak sesuaian syariah yaitu terkait adanya sewa kembali atas objek sewa. Dalam hal ini pelanggan masih mempunyai hak dan wewenang atas manfaat yg tidak sepenuhnya dilepas kepada pihak ketiga dan poin kelima adanya kesesuaian syariah terkait resiko yang ditanggung oleh musta’jir bawasannya pelanggan tidak menanggung resiko kerugian atas pemanfaatan objek tersebut kecuali

EKSISBANK (Ekonomi Syariah dan Bisnis Perbankan), Volume 5, Nomor 1, Juni 2021 
karena resiko kerugian atas yang dilakukan oleh pelanggan dengan melanggar ketentuan yang berlaku.

Tabel 4.5

Ketentuan terkait $\boldsymbol{U j r a h}$

\begin{tabular}{|c|c|c|c|}
\hline No & $\begin{array}{c}\text { Ketentuan } \\
\text { Terkait Ujrah }\end{array}$ & Sesuai & $\begin{array}{l}\text { Tidak } \\
\text { Sesuai }\end{array}$ \\
\hline 1. & $\begin{array}{l}\text { Ujrah boleh } \\
\text { berupa uang, } \\
\text { manfaat barang, } \\
\text { jasa, atau barang } \\
\text { yang boleh } \\
\text { dimanfaatkan } \\
\text { menurut syariah } \\
\text { (mutaqawwam) } \\
\text { dan peraturan } \\
\text { perundang- } \\
\text { undangan yang } \\
\text { berlaku. }\end{array}$ & $\sqrt{ }$ & \\
\hline 2. & $\begin{array}{l}\text { Kuantitas dan/atau } \\
\text { kualitas ujrah } \\
\text { harus jelas, baik } \\
\text { berupa angka } \\
\text { nominal, } \\
\text { prosentase tertentu, } \\
\text { atau rumus yang } \\
\text { disepakati dan } \\
\text { diketahui oleh para } \\
\text { pihak yang } \\
\text { melakukan akad. }\end{array}$ & $\sqrt{ }$ & \\
\hline 3. & $\begin{array}{l}\text { Ujrah boleh } \\
\text { dibayar secara } \\
\text { tunai, } \\
\text { bertahap/angsur, } \\
\text { dan tangguh } \\
\text { berdasarkan } \\
\text { kesepakatan sesuai } \\
\text { dengan syariah } \\
\text { dan/atau peraturan } \\
\text { perundang- } \\
\text { undangan yang } \\
\text { berlaku. }\end{array}$ & & $\sqrt{ }$ \\
\hline
\end{tabular}

\begin{tabular}{|l|l|c|c|}
\hline No & $\begin{array}{c}\text { Ketentuan } \\
\text { Terkait } \text { Ujrah }\end{array}$ & Sesuai & $\begin{array}{l}\text { Tidak } \\
\text { Sesuai }\end{array}$ \\
\hline 4. & $\begin{array}{l}\text { Ujrah yang telah } \\
\text { disepakati boleh } \\
\text { ditinjau-ulang atas } \\
\text { manfaat yang } \\
\text { belum diterima } \\
\text { oleh musta'jir } \\
\text { sesuai } \\
\text { kesepakatan. }\end{array}$ & $\sqrt{ }$ & \\
\hline
\end{tabular}

Tabel 4.5 di atas menunjukan antara fatwa dan dan hasil wawancara dan observasi poin pertama adanya kesesuaian syaria'ah yang terkait ujrah boleh berupa uang, manfaat, barang atau jasa dalam hal ini sewa menyewa IndiHome ujrah dibayar dalam bentuk uang. Poin kedua adanya kesesuaian syariah terkait kejelasan kuantitas dan kualitas ujrah, dalam hal sewa menyewa IndiHome bahwa ujrah atau biaya yang dikenakan kepada pelanggan dijelaskan sesuai dengan paket yang dipilih oleh pelanggan serta ketentuan kualitas yang didapat oleh pelanggan. Poin ketiga adanya ketidak sesuaian syariah terkait pembayaran ujrah di dalam sewa menyewa IndiHome pembayaran tidak bisa dilakukan dengan cara diangsur atau bertahap. Poin keempat adanya kesesuaian syariah tentang peninjauan ulang ujrah terhadap manfaat dalam sewa menyewa IndiHome bisa dilaporkan kepada kantor IndiHome jika salah satu paket tidak digunakan maka akan dikurangi pembayaran ujrahnya.

\section{KESIMPULAN}

Hasil dari penelitian ini adalah Sewa menyewa IndiHome merupakan bentuk transaksi dalam salah satu produk PT. Telkom Kandatel Purwakarta. Mekanisme yang dilakukan dalam sewa menyewa IndiHome memiliki ketentuan sesuai prosedur perusahaan, sewa menyewa ini terjadi dengan 
PT. Telkom Kandatel Purwakarta sebagai mu'jir dan pelanggan sebagai musta'jir yang melakukan transaksi sewa dengan modem sebagai objeknya. Proses transaksi dilakukan dengan pelanggan registrasi melalui offline dan online ke PT.Telkom kemudian melakukan akad atau perjanjian dengan rukun dan syarat maupun ketentuan objek ijarah dalam fatwa tersebut yang telah ditentukan selanjutnya dilakukan pembayaran administrasi pemasangan untuk pembayaran pemakaian dilakukan setelah pelanggan menggunakan IndiHome selama satu bulan. . Pemutusan dapat dilakukan dengan dua pihak atau sebelah pihak. Dua pihak dilakukan jika pelanggan melakukan pemutusan kontrak sesuai dengan prosedur Kemudian pemutusan secara sepihak hanya dilakukan oleh pelanggan tanpa persetujuan pihak Telkom. .

Mekanisme sewa menyewa IndiHome dalam perspektif ekonomi Islam, sewa menyewa IndiHome termasuk kedalam sewa menyewa yang tidak sesuai dengan ketentuanketentuan Fatwa Dewan Syariah Nasional Majelis Ulama Indonesia No. 112/DSNMUI/IX/2017. Dikarenakan adanya beberapa poin yang tidak sesuai, poin-poin tersebut yaitu pertama terkait mu'jir dan mustajir dalam sewa manyewa IndiHome jika ditinjau di lapangan kebanyakan pelanggan belum cakap hukum sesuai dengan syariah dan peraturan perundang-undangan, kedua terkait manfaat dan waktu dalam sewa menyewa IndiHome kurang jelas penentuan waktu berahkirnya akad karena dalam IndiHome akan terus berlanjut bila pelanggan masih ingin menggunkannya dan tentang pelanggan IndiHome juga tidak bisa menyewakan kembali kepada pihak ketiga berbeda dengan ketentuan fatwa, ketiga tentang ujrah dalam ketentuan fatwa ujrah boleh dibayar secara tunai, bertahap/angsur, dan tangguh berdasarkan kesepakatan sesuai dengan syariah dan/atau peraturan perundang- undangan yang berlaku sedangkan dalam transaksi sewa menyewa IndiHome pembayaran tidak boleh secara angsur.

\section{DAFTAR PUSTAKA}

Admin. 2019. "Profil Dan Riwayat PT. Telkom." PT. Telkom Indonesia.

Afandi, M. Yazid. 2010. Fiqh Muamalah. Yogyakarta: Logung Pustaka.

Agus Putra, Panji Adam, Redi Hadiyanto, Indra Wijaya, and Dina Rahmania. 2020. "The Legality Of Hybrid Contract On Sbsn (Sukuk) Ijarah Sale And Lease Back In DSN-MUI Fatwa." Laa Maisyir : Jurnal Ekonomi Islam 7(2): 277. http://journal.uin-

alauddin.ac.id/index.php/lamaisyir/articl e/view/15044.

Arikunto, Suharsimi. 2016. Manajemen Penelitian. Jakarta: Rineka Cipta.

Fina Anisa, 121310021. 2018. "Klausula Eksemsi Dalam Kontrak Berlangganan Internet PT.Telekomunikasi Indonesia Wilayah Aceh Ditinjau Menurut Konsep Perlindungan Konsumen Dalam Hukum Islam (Suatu Penelitian Di Kota Banda Aceh)."

Ghazaly, Abdul Rahman, Ghufron Ihsan, and Sapiudin Shidiq. 2010. Fiqh Muamalah. Jakarta: Kencana Prenada Media Group.

Hasan, M. Ali. 2003. Berbagai Macam Transaksi Dalam Islam (Fiqh Muamalat). Jakarta: Raja Grafindo Persada.

Jaelani, Sandi, Imam Sucipto, and Jalaludin Jalaludin. 2020. "Implementasi Pembiayaan Ultra Mikro Berdasarkan Prinsip Syariah Di KSPPS BMT Purwakarta Amanah Sejahtera (PAS)." EKSISBANK (Ekonomi Syariah dan Bisnis Perbankan)2 4(2): 112-39.

Jalaludin, Jalaludin, and Heru Komarujaman. 
2018. "Talent Management Dalam Meningkatkan Kinerja Lembaga KSPPS BMT Mitra Sadaya Cabang Purwakarta." EKSISBANK: Ekonomi Syariah dan Bisnis Perbankan 2(1). http://journal.stiespurwakarta.ac.id/index.php/EKSISBAN K/article/view/9.

McQuail, Denis. 2011. Teori Komunikasi Massa, Diterjemahkan Oleh Putri Iva Izzati. Jakarta: Salemba Humanika.

Meirani, Raden Andriana, Ahmad Damiri, and Jalaludin Jalaludin. 2020. "Penerapan Akad Murabahah Pada Produk MULIA Di Pegadaian Jalancagak Menurut Perspektif Ekonomi Syariah." EKSISBANK: Ekonomi Syariah dan Bisnis Perbankan 4(1): 60-68. http://www.journal.stiespurwakarta.ac.id/index.php/EKSISBAN K/article/view/69 (October 28, 2020).

Moleong, Lexy J. 2017. Metodologi Penelitian Kualitatif. Bandung: Remaja Rosdakarya.

MUHAMMAD, KHOIRUL IQBAL. 2021. "TINJAUAN HUKUM ISLAM TERHADAP PEMBAYARAN UPAH TAMBAHAN PEMASANGAN WIFI INDIHOME (Studi Di Kelurahan Susunan Baru, Kecamatan Tanjung Karang Barat,Bandar Lampung).”

Sari, Ratna et al. 2019. 4 Jurnal Penelitian Hukum Ekonomi Islam Perjanjian Kemitraan Antara PT. Go-Jek Cabang Cirebon Dengan Mitra Pengendara Dalam Prespektif Hukum Islam Dan Hukum Perdata. https://www.syekhnurjati.ac.id/jurnal/in dex.php/al-mustashfa/article/view/5493 (May 31, 2021).

Setiaji, Ari Candra. 2017. PERLINDUNGAN HUKUM KONSUMEN INDIHOME
TERHADAP. Universitas Islam Indonesia.

Sugiyono. 2013. Metodelogi Penelitian Kuantitatif, Kualitatif Dan R\&D. Bandung: Alfabeta.

- 2016. Metodologi Penelitian Kuantitatif, Kualitatif Dan $R \& D$. Bandung: Alfabeta. 2017. Metode Penelitian Kuantitatif, Kualitatif, Dan R\&D. Bandung: Alfabeta.

Suripto, Teguh, and Abdullah Salam. 2018. "Analisa Penerapan Prinsip Syariah Dalam Asuransi." JESI (Jurnal Ekonomi Syariah Indonesia) 7(2): 128. http://ejournal.almaata.ac.id/index.php/J ESI/article/view/593.

Suryani, and Hendryadi. 2015. Metode Riset Kuantitatif Teori Dan Aplikasi Pada Penelitian Bidang Manajemen Dan Ekonomi Islam. Jakarta: Prenademedia Group.

Syafei, Rachmat. 2011. FIQIH Muamalah. Bandung: Pustaka Setia.

ULUL AZMI, FAHRUL. 2021. "WANPRESTASI DALAM KONTRAK BERLANGGANAN LAYANAN INDIHOME (Suatu Penelitian Pada PT. Telkom Indonesia Banda Aceh)."

Zuhaili, Wahbah. 2010. Al-Fiqhu Asy-Syafi"i Al-Muyassar, Diterjemahkan Muhammad Afifi, Abdul Hafiz (Fiqih Imam Syafi"i 2). Jakarta: Almahira.

EKSISBANK (Ekonomi Syariah dan Bisnis Perbankan), Volume 5, Nomor 1, Juni 2021 http://journal.sties-purwakarta.ac.id/index.php/EKSISBANK/ 